\title{
Chemometric analysis of antioxidant activity and anthocyanin content of selected wild and cultivated small fruit from Serbia
}

\author{
Violeta MItic $^{1 *}$, Vesna Stankov Jovanovic ${ }^{1}$, Marija DimitRIJeVIc ${ }^{1}$, Jelena CVetKovic ${ }^{1}$, Strahinja Simonovic ${ }^{1}$, Snezana Nikolic Mandic ${ }^{2}$
}

1 Univ. Nis, Fac. Sci. Math., Dep. Chem., Visegradska 33, Nis, Serbia,

violetamitic@yahoo.com

2 Univ. Belgrade, Fac. Chem., Belgrade, Serbia

${ }^{*}$ Correspondence and reprints

Received October 20, 2013 Accepted January 30, 2014

Fruits, 2014, vol. 69, p. 413-422 (C) 2014 Cirad/EDP Sciences All rights reserved

DOI: $10.1051 /$ fruits/2014026

www.fruits-journal.org

RESUMEN EsPañol, p. 422
Chemometric analysis of antioxidant activity and anthocyanin content of selected wild and cultivated small fruit from Serbia.

Abstract - Introduction. The fruit types such as raspberries (Rubus idaeus), cherries (Prunus cerasus), blackberries (Rubus fructicosus), blackthorns (Prunus spinosa) and aronia (Aronia melanocarpa) are very common in Serbia. These fruit species are a valuable source of antioxidants. The goal of our work was to evaluate the antioxidant activities of ethyl acetate extracts of these five berries and to establish possible correlation between the content of anthocyanin and the antioxidant activity. Materials and methods. To determine antioxidant activity of the selected fruits, the DPPH (2,2-diphenyl-1-picrylhydrazyl) radical scavenging activity, the ABTS (2,2-azinobis-3 ethyl benzothiazoline-6-sulfonic acid) cation decolorization activity, the FRAP (ferric reducing antioxidant power), and the TRP (total reducing power) were measured. Results. The four methods selected for our assays showed strong antioxidant properties for blackberry samples. The total anthocyanin content was estimated using the $\mathrm{pH}$ differential method. The highest amount of anthocyanin was found in blackberry samples [(1063.53 \pm 0.01$) \mathrm{mg} \cdot \mathrm{kg}^{-1}$ fresh fruit], while the lowest was in raspberry samples [(180.84 \pm 0.02$) \mathrm{mg} \cdot \mathrm{kg}^{-1}$ fresh fruit]. The correlation between the content of anthocyanin and antioxidant activity was established using regression analysis. The highest correlation was found between total reducing power and total anthocyanin $(r=0.97, p<0.05)$. Hierarchical cluster analysis divided selected fruit species into two statistically significant clusters. Conclusion. Our results confirmed that analyzed berries are rich in anthocyanins. A strong correlation among different assays as well as with anthocyanin content was observed. Cluster analysis can be used in food science, to classify different food types into groups, based on similarity among the results.

Serbia / Rubus idaeus / Prunus cerasus / Rubus fructicosus / Prunus spinosa / Aronia melanocarpa / fruits / antioxidants / anthocyanins / methodology

Analyse chimiométrique de l'activité antioxydante et de la teneur en anthocyanes de petits fruits sauvages et cultivés de Serbie.

Résumé-Introduction. Les fruits comme les framboises (Rubus idaeus), les cerises (Prunus cerasus), les mûres (Rubus fructicosus), les prunelles (Prunus spinosa) et Aronia melanocarpa sont très fréquents en Serbie. Ces fruits sont une précieuse source d'antioxydants. Le but de notre travail a été d'évaluer les activités antioxydantes des extraits d'acétate d'éthyle de ces cinq petits fruits et d'établir une corrélation possible entre le contenu des anthocyanes et l'activité antioxydante. Matériel et méthodes. Pour déterminer l'activité antioxydante des fruits sélectionnés, les méthodes DPPH (2,2-diphényl-1-picrylhydrazyl), ABTS (acide 2,2-azinobis-3 d'éthyle d'acide benzothiazoline-6-sulfonique), FRAP (pouvoir antioxydant de réduction du fer) et TRP (pouvoir réducteur total) ont été utilisées sur des extraits des cinq fruits sélectionnés. Résultats. Les quatre méthodes retenues pour nos essais ont révélé les grandes propriétés antioxydantes des échantillons de mûres. La teneur en anthocyanes totale a été estimée en utilisant la méthode de la différence de $\mathrm{pH}$. La teneur la plus élevée en anthocyanes a été trouvée dans les échantillons de mûres $\left[(1063,53 \pm 0.01) \mathrm{mg} \cdot \mathrm{kg}^{-1}\right.$ matière fraîche], et la plus faible dans les échantillons de framboises [(180,84 \pm 0.02$) \mathrm{mg} \cdot \mathrm{kg}^{-1}$ matière fraîche]. La corrélation entre la teneur en anthocyanes et l'activité antioxydante a été établie par analyse de régression. La plus forte corrélation a été trouvée entre la méthode TRP et les anthocyanes totaux $(r=0,97, p<0,05)$. L'analyse de classification hiérarchique a divisé les espèces fruitières sélectionnées en deux groupes statistiquement significatifs. Conclusion. Nos résultats ont confirmé que les fruits analysés étaient riches en anthocyanes. Une forte corrélation entre l'utilisation des différentes méthodes et la teneur en anthocyanines a été observée. L'analyse typologique pourrait être utilisée dans la science des aliments pour classer différents types de production dans des groupes en se basant sur une similarité entre les résultats.

Serbie / Rubus idaeus / Prunus cerasus / Rubus fructicosus / Prunus spinosa / Aronia melanocarpa / fruits / antioxydant / anthocyane / méthodologie 


\section{Introduction}

Antioxidants are compounds able to inhibit oxidation of lipids, proteins, carbohydrates and DNA in the human body. Some of the antioxidants also act as the radical traps that protect the human body from free radicals. Free radicals can cause pathological conditions such as anemia, asthma, arthritis, inflammation, and Parkinson's disease [1]. Epidemiological studies have confirmed that natural antioxidants may prevent development of diseases caused by reactive oxygen species (ROS). Therefore, by eating food rich in natural antioxidants (fruits, vegetables, natural juices, teas, cereals, wines, chocolates, etc.) the development of diseases caused by oxidative stress is prevented.

Antioxidants can be classified as preventing, scavenging and repairing antioxidants [2]. Preventing antioxidants act as the first line of defense by inhibiting the formation of reactive nitrogen and oxygen species. Scavenging antioxidants remove formed reactive species before they interact with biologically essential molecules. Many phenolic compounds and aromatic amines act as scavenging antioxidants. Various enzymes function in the third line of defense by repairing damage and reconstituting lost functions. According to the solubility of antioxidants, they can be classified into hydrosoluble (vitamin C, uric acid, bilirubin, albumin, glutathione and some polyphenols) and liposoluble (vitamins $\mathrm{A}$ and $\mathrm{E}$, carotenoids) [3]

Fruits are the source of essential nutrients such as minerals, vitamins and non-essential compounds, like polyphenols [4] Phenolic compounds contribute to the antioxidant activity of fruits and vegetables. The antioxidant activity of phenolic compounds is related to the capture of free radicals and binding of metal ions, which are precursors in the formation of free radicals [5]. Studies have shown that polyphenols protect the heart, blood vessels and the immune system, and their impact on the aging process and cancer development is widely investigated [6].
Berries have special significance in Serbia because they represent an important export product. Serbia is one of the leading countries for raspberry and blackberry production. Various studies have confirmed that berries from the Ericaceae (blueberry) and Rosaceae (blackberry, raspberry, cherry and strawberry) families contain significant amounts of antioxidants [7-10]. As with other fruits and vegetables, berries are important dietary sources of fibers, vitamins, and minerals [11]. Antioxidant properties of dark colored fruit are associated with the polyphenol and anthocyanin content [12]. Berries are good sources of natural antioxidants [13], including phenolic compounds like flavonoids, anthocyanins, or vitamin C [14]. Different phenolic compounds occur in different cultivars and their relative quantities and proportion may also vary [15]. The differences affect the total antioxidant capacity, and the anticarcinogenic and antimutagenic activities [16]

A diet rich in these fruits protects the human body from many diseases, including cancer [17], heart attack [18] and Alzheimer's disease [19].

The aim of our study was to examine the antioxidant activity of cherries, raspberries, blackthorns, aronia and blackberries (their ethyl acetate extracts) and to establish the correlation to the total anthocyanin content. We used four methods to evaluate antioxidant activity in order to consider different possible mechanisms of action. Cluster analysis was used to trace similarities or differences between different fruit species.

\section{Materials and methods}

\subsection{Fruit samples}

Cherries (Prunus cerasus), raspberries (Rubus idaeus), blackberries (Rubus fructicosus), blackthorns (Prunus spinosa) and aronia (Aronia melanocarpa) were collected at full maturity in Nis $\left(43^{\circ} 18^{\prime} 0^{\prime \prime} \mathrm{N}\right.$,

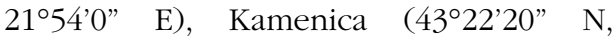
$\left.21^{\circ} 56^{\prime} 19^{\prime \prime} \mathrm{E}\right)$ and Oblacina lake (4318'17" N, $21^{\circ} 40$ '44” E), southern Serbia. Prior to the 
extractions, whole fresh fruits were kept in the refrigerator at $-18^{\circ} \mathrm{C}$.

\subsection{Chemicals and instruments}

Chemicals and reagents were purchased from Merck (Darmstadt, Germany). Spectrophotometric assays were performed on a double-beam UV-VIS spectrophotometer Perkin Elmer lambda 15 (Massachusetts, USA).

\subsection{Extraction}

Phenolic compounds were extracted from the fruits with ethyl acetate [20]. Frozen fruits were homogenized in a blender and $6 \mathrm{~g}$ of material was mixed successively with $10 \mathrm{~mL}$ portions of ethyl acetate. The procedure was repeated four times. Part of the extract $(20 \mathrm{~mL})$ was evaporated to dryness $\left(35^{\circ} \mathrm{C}\right)$ and the dry residue was dissolved in $4 \mathrm{~mL}$ of methanol.

\subsection{Anthocyanins}

Total anthocyanin content was measured with the $\mathrm{pH}$ differential absorbance method based on the structural change of the anthocyanin chromophore between $\mathrm{pH} 1.0$ and $\mathrm{pH} 4.5$ [21]. Monomeric anthocyanins undergo a reversible structural transformation as a function of $\mathrm{pH}$ (colored oxonium form at $\mathrm{pH} 1.0$ and colorless hemiketal form at $\mathrm{pH} 4.5$ ). Thus, the difference in absorbance at the $\lambda=510 \mathrm{~nm}$ of the pigment is proportional to its concentration. Two dilutions of fruit samples were prepared by mixing fresh fruit with buffer ( $\mathrm{pH} 1.0$ and 4.5). This procedure was performed on each of the fruit samples. After $15 \mathrm{~min}$, the absorbance of prepared solution was measured at $\lambda=510 \mathrm{~nm}$. Anthocyanin content (ANT) was expressed as equivalents of cyanidin3-glucoside per mass of the fruits fresh weight $\left(\mathrm{mg} \cdot \mathrm{kg}^{-1}\right)$ :

$\operatorname{ANT}\left(\frac{m g}{k g}\right.$ f.W. $)=\left(\mathrm{A}_{\mathrm{pH} 1}-\mathrm{A}_{\mathrm{pH} 4.5}\right) *\left(\frac{484.8}{24825}\right) * 20000$, where $A_{\mathrm{pH}} 1$ is absorbance of solution at
pH 1 and $\mathrm{A}_{\mathrm{pH}} 4.5$ is absorbance of solution at $\mathrm{pH} 4.5$.

\subsection{DPPH radical scavenging assay}

Antioxidant properties of the extracts were tested by applying the method based on the reaction of antioxidants with 2,2-diphenyl1-picryl hydrazil radical (DPPH), and results were expressed as trolox equivalents (TE) [22]. Absorbance of the reaction mixtures, prepared by mixing ethyl acetate extracts of fruits with a DPPH solution, was measured after an hour at $\lambda=515 \mathrm{~nm}$.

Absorbance of the reaction mixture was measured in intervals of $60 \mathrm{~s}$ during the first $5 \mathrm{~min}$ of the reaction, and, after first $5 \mathrm{~min}$, the interval of measurements was changed to $5 \mathrm{~min}$. Overall reaction time was $20 \mathrm{~min}$. The concentration of remaining DPPH radical was calculated from the calibration curve of DPPH, and the results were presented as a graphical dependency of remaining DPPH percentage of time.

\subsection{ABTS radical scavenging assay}

The ABTS radical scavenging assay is based on the ability of antioxidants to scavenge the radical cation 2,2'-azinobis (3-ethyl-benzothiazoline-6-sulfonate) $\left(\mathrm{ABTS}^{+}\right)$. ABTS radical was produced by the reaction of ABTS stock solution $\left(7 \times 10^{-3} \mathrm{~mol} \cdot \mathrm{dm}^{-3}\right)$ with $2.4 \times 10^{-3} \mathrm{~mol} \cdot \mathrm{dm}^{-3}$ potassium persulfate and allowing the mixture to stand in the dark at room temperature for $12-16 \mathrm{~h}$ before use [23]. Absorbance of the working solution was adjusted to 0.7. Fruit extracts were added to the working solution and after $6 \mathrm{~min}$ at room temperature, decrease of the absorbance was measured at $734 \mathrm{~nm}$. Results were expressed as trolox equivalents per mg of dry weight.

\subsection{Ferric reducing antioxidant power assay}

The ferric reducing antioxidant power (FRAP) assay involved reduction of ferric tripyridyl triazine (Fe (III) TPTZ) complex to ferrous form in the presence of antioxidants 
which was revealed as the increase of absorption at $595 \mathrm{~nm}$ [24]. FRAP values, expressed as $\mathrm{Fe}$ (II) equivalents per mg dry weight, was obtained by comparing the change of the absorption in the test mixture with those obtained from the Fe(II) standard calibration curve.

\subsection{Total reducing power assay}

This total reducing power (TRP) assay is based on the ability of antioxidants to react with metal ions, when reduction of Fe(III) hexacyanate to $\mathrm{Fe}(\mathrm{II})$ hexacyanate takes place [25]. Reaction mixtures were prepared by mixing $20 \mu \mathrm{L}$ of the extract, $2 \mathrm{~mL}$ of $1 \%$ solution $\mathrm{K}_{3}\left[\mathrm{Fe}(\mathrm{CN})_{6}\right]$, phosphate buffer and water. The mixtures were incubated at $50{ }^{\circ} \mathrm{C}$ for $30 \mathrm{~min}$, then the solution of trichloroacetic acid (10\%) and $\mathrm{FeCl}_{3}$ was added Absorbance of obtained mixtures was measured at $\lambda=700 \mathrm{~nm}$; results were expressed as ascorbic acid equivalents per mg of dry weight.

\subsection{Statistical analysis}

All analyses were performed in triplicate, with a maximum error of less than 5\%. Statistical analysis was performed by paired Student $t$ test. A probability of $p<0.05$ was considered to be statistically significant. Regression analysis was performed in Microsoft Excel-2007. Correlation between antioxidant characteristics and anthocyanin content was established using regression analysis at a 95\% significance level $(P<0.05)$. Cluster analysis is used for finding different classes and groups within the obtained data. Hierarchical cluster analysis (HCA) has been reported in several publications for the analysis of foodstuffs [26, 27]. The cluster analysis was done by the mean of Ward's method using Euclidean distances as a measure of similarity. The linkage distance was reported as $\mathrm{D}_{\text {link }} / \mathrm{D}_{\max }$, which represents the quotient between the linkage distances for a particular case divided by the maximal linkage distance. The data derived from this study (table II) were originally centered by logarithmic transformation with all variables standardized. STATISTICA 7 (StatSoft, Inc., Tulsa, OK, USA) software was used to compile the dendrogram.

\section{Results and discussion}

Significant differences in anthocyanin content among selected fruit species were recorded (table I). Blackberries contained the highest quantity of anthocyanins expressed as cyanidin-3-glucoside (1063.53 $\mathrm{mg} \cdot \mathrm{kg}^{-1}$ fresh weight), followed by cherries and aronia [(929.57 and 780.37) $\mathrm{mg} \cdot \mathrm{kg}^{-1} \mathrm{fw}$, respectively], whereas blackthorns and raspberries contained the lowest amounts of anthocyanins [(461.27 and 180.84$) \mathrm{mg} \cdot \mathrm{kg}^{-1} \mathrm{fw}$, respectively]. Similar results for anthocyanin content have

\section{Table I.}

Anthocyanin contents of five selected wild and cultivated small fruit from Serbia expressed as cyanidin 3-glucoside equivalents.

\section{Sample}

Raspberry

Aronia

Cherry

Blackthorn
Anthocyanin

( $m g$ cyanidin-3-glucoside Eq $\cdot \mathrm{kg}^{-1}$ fresh fruit)

$$
\begin{gathered}
1063.53 \pm 0.01 \mathrm{c} \\
180.84 \pm 0.02 \mathrm{a} \\
780.37 \pm 0.01 \mathrm{~b} \\
929.57 \pm 0.02 \mathrm{c} \\
461.27 \pm 0.03 \mathrm{~b}
\end{gathered}
$$

Values are the mean \pm standard deviation $(n=3)$. Values with different letters within columns are statistically different at $p<0.05$ by paired Student $t$ test. 
been reported by other researchers [28, 29]. Anthocyanins are responsible for red, purple, and blue pigments present in fruits, vegetables, and grains [30]. They have been claimed to possess various biological properties and therefore are considered as secondary metabolites with potential nutritional value. Anthocyanins in general were claimed to exhibit protection against DNA oxidative damage [31], peroxynitrile scavenging [32] and antioxidant and antiinflammatory function [33]. The anthocyanin structure is $\mathrm{pH}$ dependent, and that is the base for their quantification. Berries evaluated in our study showed significant variations in total anthocyanin content.

Flavonols and phenolic acids were extracted from fruit samples according to the extraction process already described in the literature [20]. Ethyl acetate is the best solvent for extraction of phenolic acids [34, 35]. Polyphenols exist in their natural forms in extracts - heterosides of flavonols, phenolic acids and anthocyanins. Also, phenolic acids can be found in the form of esters. Heterosides are stronger antioxidants than the corresponding aglycones [36]. Since the heterosides of flavonols, phenolic acids and anthocyanins were extracted and directly applied in estimation of antioxidant properties, obtained results can be considered as a true indicator of fruit significance in healthcare, regarding active antioxidant compounds.

The DPPH method is one of the most commonly used methods to evaluate antioxidant activity. It is based on the reduction of purple 2,2-difenilenil-1-picrylhydrazyl radical (DPPH ) to yellow hydrazine. DPPH radical is relatively stable, at it can be reduced only by the reactive compounds, such as phenolic compounds [37]. The kinetics of phenolic compounds and DPPH radical reaction was different according to the fruit species studied (figure 1). The percentage of remaining DPPH radical decreases as the reaction progresses. After addition of fruit extracts to the reaction medium, the absorbance of DPPH at $515 \mathrm{~nm}$ decreases, due to the decrease of DPPH concentration. Blackthorn showed the lowest "scavenging" capacity, by decreasing the DPPH concentration from

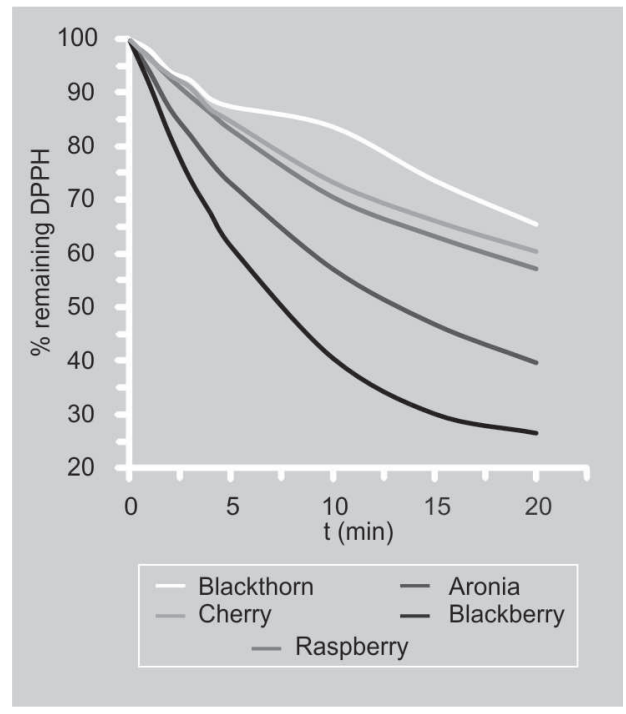

Figure 1.

Kinetics of 2,2-diphenyl-1picryl hydrazil radical (DPPH) and phenolic compounds reaction for five small fruits selected from Serbia. A color figure is available at www.fruits-journal.org
$100 \%$ to $65.34 \%$, while blackberries showed the highest "scavenging" capacity, by decreasing the DPPH concentration from $100 \%$ to $26.54 \%$. DPPH reaction is timedependent and it can last from $20 \mathrm{~min}$ to $6 \mathrm{~h}$. Antioxidants react with the stable DPPH radical and transform it. In the first 5 min of the reaction, the difference in remaining DPPH percentage for different extracts is not significant. The highest rate of DPPH decay occurs within the first 10 min of the reaction (figure 1). The longer the reaction time, the higher the difference between the remaining DPPH radicals.

Antioxidant activity of fruit extracts depends on the applied method. The analyst should therefore be very careful when interpreting antioxidant capacities from different assays [38, 39].

The antioxidant properties of selected fruits were assessed by applying the most widely used assays - DPPH, ABTS, FRAP and TRP (table II). According to the DPPH assay, blackberry extract showed the highest "scavenging" activity [ 0.2125 $\pm 0.0064) \mu \mathrm{mol}$ trolox $\mathrm{Eq} \cdot \mathrm{mg}^{-1}$ dry weight], while the lowest was recorded for raspberry $\left[(0.0725 \pm 0.0035) \mu \mathrm{mol}\right.$ trolox Eq $\left.\cdot \mathrm{mg}^{-1} \mathrm{DW}\right]$. The ABTS assay showed similar results. Antioxidant activities varied between $(0.1576 \pm 0.0049) \mu \mathrm{mol}$ trolox $\mathrm{Eq} \cdot \mathrm{mg}^{-1} \mathrm{DW}$ for raspberry to $(0.3616 \pm 0.0028) \mu \mathrm{mol}$ trolox $\mathrm{Eq} \cdot \mathrm{mg}^{-1}$ DW for blackberry. Antioxidant 
activity of fruit determined by the ABTS radical cation scavenging assay decreased in the following order: blackberry $>$ cherry $>$ aronia $>$ blackthorn $>$ raspberry. The other two methods, based on the $\mathrm{Fe}$ (III)/Fe(II) redox reaction, confirmed the remarkable antioxidant activity of blackberry. According to the FRAP assay, blackberries had the highest antioxidant activity [(1.0900 \pm 0.0049) $\mu \mathrm{mol} \mathrm{Fe} \cdot \mathrm{mg} \mathrm{dw}$, and raspberries demonstrated the lowest antioxidant activity $[(0.3780 \pm 0.0049) \mu \mathrm{mol} \mathrm{Fe} / \mathrm{mg} \mathrm{dw}]$. The highest total reducing power is recorded for blackberry $[(0.1920 \pm 0.0042) \mu \mathrm{mol}$ ascorbic acid $\mathrm{Eq} \cdot \mathrm{mg}^{-1} \mathrm{dw}$, and the lowest for raspberry $[(0.1180 \pm 0.0035) \mu \mathrm{mol}$ ascorbic acid $\left.\mathrm{Eq} \cdot \mathrm{mg}^{-1} \mathrm{dw}\right]$.

Considering the antioxidant potential of selected wild and cultivated fruits consumed in Serbia due to their phenolic (phenolic acids and flavonoids) and carotenoid content, we measured the antioxidant capacity, based on the reducing power of such antioxidants against the ferric tripyridyltriazine (Fe(III)-TPTZ) complex. In the present study, we used the ferric reducing power assay because of its simplicity and reproducibility, the FRAP assay confirmed the highest antioxidant activity for blackberries $\left[(1.0900 \pm 0.0049) \mu \mathrm{mol} \mathrm{Fe} \cdot \mathrm{mg}^{-1} \mathrm{dw}\right]$. The highest total reducing power is recorded for blackberry $[(0.1920 \pm 0.0042) \mu \mathrm{mol}$ ascorbic acid $\left.\mathrm{Eq} \cdot \mathrm{mg}^{-1} \mathrm{dw}\right]$, and the rankings were blackberry $>$ cherry $>$ aronia $>$ blackthorn $>$ raspberry.
Previous studies have shown that the ABTS assay underestimates antioxidant activity of plant extracts, while DPPH radical, due to steric effects, reacts easily only with small molecules [40]. The FRAP assay is simple and rapid, but the reaction must be performed in acidic conditions $(\mathrm{pH}=3.6)$ and, for all other assays performed, the reaction is carried out in weakly acidic or neutral medium. The different in vitro antioxidant activity tests show different results [38-41], so the variation between results is expected. According to all assays used in our study, blackberries proved to possess the highest antioxidant activity, while results for other fruit species varied depending on the applied method. Pellegrini et al. have shown differences in results for antioxidant activity using FRAP and ABTS assays [42], so it is difficult to select a suitable antioxidant assay.

Statistical analysis was used for investigating the correlation between antioxidant activity and total anthocyanin content and the relations among different antioxidant assays (table III). Antioxidant properties were correlated to the total anthocyanin content. The highest correlation was found between total reducing power and total anthocyanin $(r=0.972664, p<0.05)$. The statistical analysis showed a positive and highly significant (0.768148-0.824338, $p<0.05$ ) correlation between other applied methods and total anthocyanin content.

Table II.

Results of 2,2-diphenyl-1-picryl hydrazyl radical (DPPH) radical scavenging assay, 2,2'-azinobis (3-ethylbenzothiazoline-6-sulfonate) (ABTS) radical scavenging assay, total reducing power (TRP) assay, ferric-ion reducing antioxidant power (FRAP) assay of selected wild and cultivated small fruit from Serbia

\begin{tabular}{|c|c|c|c|c|}
\hline Sample & $\begin{array}{c}\mathrm{DPPH} \\
\left(\mu \mathrm{mol} \text { trolox Eq} \cdot \mathrm{mg}^{-1} \mathrm{dw}\right)\end{array}$ & $\begin{array}{c}\text { ABTS } \\
\left(\mu \mathrm{mol} \text { trolox Eq } \cdot \mathrm{mg}^{-1} \mathrm{dw}\right)\end{array}$ & $\begin{array}{c}\text { TRP } \\
\left(\mu \mathrm{mol} \text { ascorbic acid Eq } \cdot \mathrm{mg}^{-1} \mathrm{dw}\right)\end{array}$ & $\begin{array}{c}\text { FRAP } \\
\left(\mu \mathrm{mol} \mathrm{Fe} \cdot \mathrm{mg}^{-1} \mathrm{dw}\right)\end{array}$ \\
\hline Aronia & $0.1065 \pm 0.0035 b$ & $0.1808 \pm 0.0028 a$ & $0.1540 \pm 0.0049 c$ & $0.6120 \pm 0.0042 d$ \\
\hline Raspberry & $0.0725 \pm 0.0035 a$ & $0.1576 \pm 0.0049 a$ & $0.1180 \pm 0.0035$ ace & $0.3780 \pm 0.0049 \mathrm{abcd}$ \\
\hline Blackberry & $0.2125 \pm 0.0064 c$ & $0.3616 \pm 0.0028 c$ & $0.1920 \pm 0.0042 \mathrm{e}$ & $1.0900 \pm 0.0049 \mathrm{e}$ \\
\hline Cherry & $0.1030 \pm 0.0057 b$ & $0.2552 \pm 0.0021 b$ & $0.1720 \pm 0.0042 \mathrm{de}$ & $0.5660 \pm 0.0018 c$ \\
\hline Blackthorn & $0.0785 \pm 0.0049 a$ & $0.1704 \pm 0.0007 a$ & $0.1440 \pm 0.0042 \mathrm{bce}$ & $0.4100 \pm 0.0049 b$ \\
\hline
\end{tabular}

Values are the mean \pm standard deviation $(n=3)$. Values with different letters within columns are statistically different at $p<0.05$ by paired Student $t$ test. 
Some authors have explained that the antioxidant activity of fruits results mainly from phenolic and anthocyanin content Therefore the correlation between total anthocyanin content and antioxidant activity was determined. A strong correlation between antioxidant activity and total anthocyanin content was found. Anthocyanin-rich fruit showed high antioxidant activity [43], which is in agreement with our study. The results of Takahata et al. also demonstrated that cyanidin-based anthocyanins were related to DPPH radical scavenging activity in sweet potato storage roots [44].

Strong correlation was also found among selected antioxidant assays. Surprisingly marked correlation was found between the DPPH and FRAP assays $(r=0.995398)$ (table III), considering different reaction mechanisms. Assays used in our research are based on stable free radical and antioxidants reactions (ABTS and DPPH) or metal ion redox reactions (FRAP and TRP). Correlations were significant among the antioxidant assays, regardless of the reaction mechanism. The strongest correlation was found between the DPPH and FRAP assays, which is unusual considering their mechanisms. Fruits, such as the examined berries, contain polyphenolics as the predominant class of antioxidants [45]. This fact provides strong correlations among antioxidant assays based on very diverse chemical backgrounds. Different ranking orders of different types of fruits are related to different

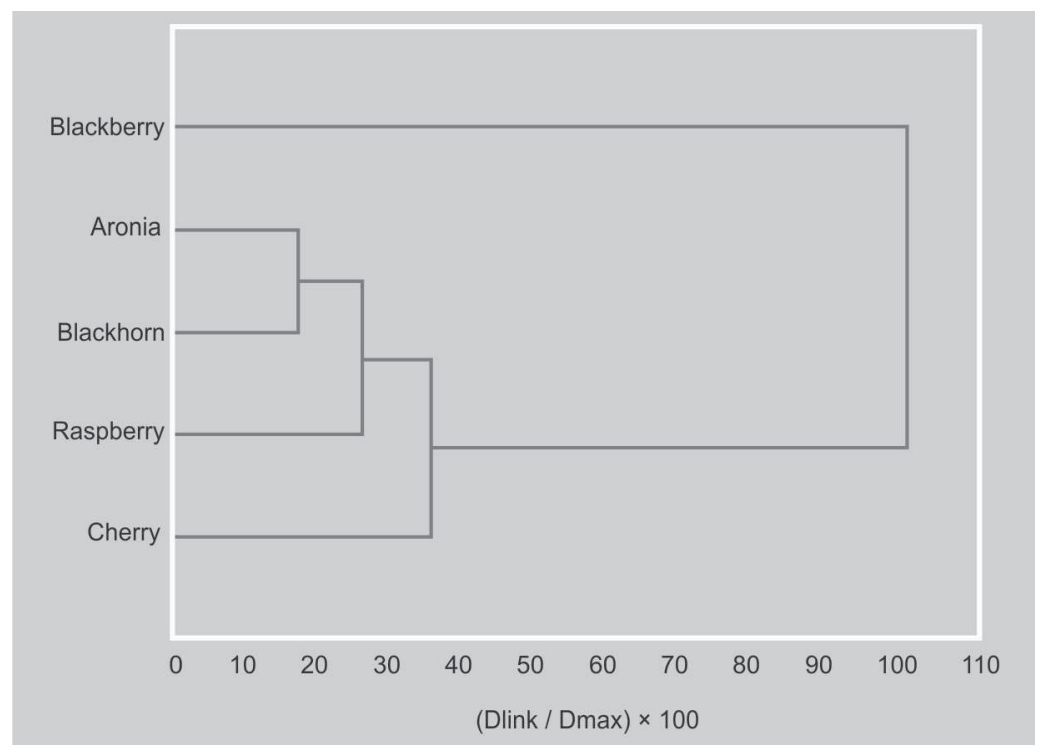

\section{Figure 2.}

Dendrogram obtained by hierarchical cluster analysis using means of 2,2-diphenyl1-picryl hydrazil radical (DPPH), 2,2'-azinobis (3-ethyl-benzothiazoline-6-sulfonate) (ABTS), ferric-ion reducing antioxidant power (FRAP) and total reducing power (TRP). $D_{\text {link }} / D_{\text {max }}$ represents the quotient between the linkage distances for a particular case divided by the maximal linkage distance (Ward's method, Euclidian distances).

reaction mechanisms and conditions (FRAP does not measure thiol antioxidants, DPPH might be interfered with by carotenoids having absorbance at $515 \mathrm{~nm}$ ).

Cluster analysis yields a dendrogram (figure 2), grouping aronia, blackthorn, raspberry and cherry into one statistically significant cluster at $\left[\left(\mathrm{D}_{\text {link }} / \mathrm{D}_{\max }\right) \times 100\right]$ $<50$, whereas blackberry does not belong to this cluster. Euclidean distance, obtained

\section{Table III.}

Correlation coefficient between fruit total anthocyanin content and results of assays used for studying anthocyanin content of five selected wild and cultivated small fruit from Serbia.

$\begin{array}{lcccc}\text { Method used } & \text { FRAP } & \text { DPPH } & \text { ABTS } & \text { Anthocyanins } \\ \text { TRP } & 0.867766 & 0.845703 & 0.909894 & 0.972664 \\ \text { FRAP } & - & 0.995398 & 0.932694 & 0.811027 \\ \text { DPPH } & - & - & 0.940693 & 0.768148 \\ \text { ABTS } & - & - & - & 0.824338\end{array}$

DPPH: 2,2-diphenyl-1-picryl hydrazyl radical.

ABTS: 2,2'-azinobis (3-ethyl-benzothiazoline-6-sulfonate).

TRP: total reducing power.

FRAP: ferric-ion reducing antioxidant power. 
following hierarchical cluster analysis (HCA), varied between 5.00 for blackberry and raspberry, to 0.94 for aronia and blackthorn.

In HCA, samples were grouped based on similarity between them. In our assays, HCA was applied to a data set of four variables (DPPH, ABTS, FRAP and TRP) and five fruit species. As expected, results described in the previous sections were confirmed. Cluster analysis revealed that aronia, blackthorn, raspberry and cherry belong to one cluster, while blackberry belongs to a separated cluster (figure 2). According to our results, aronia and blackthorn showed similar antioxidant activity. Cherry had similar antioxidant activity to aronia and blackthorn, but cluster analysis showed that raspberry is "the nearest neighbor" to aronia and blackthorn. Blackberry showed the highest antioxidant activity according to all methods used, and that is why it is in a separated cluster. The Euclidean distance between blackberry and raspberry was the highest (5.00), which is expected, according to antioxidant activity results.

\section{Conclusion}

The analyzed fruits are easy to obtain, making them even more accessible in the human diet. Results of our study confirmed that analyzed berries are rich in anthocyanins. All berries have high antioxidant activity due to health-promoting substances, however blackberry showed the highest antioxidant activity according to all four applied antioxidant methods. Although the four other species have lower antioxidant activity, they are also a valuable source of healthy compounds such as anthocyanins and phenolic compounds. Differences in results were related not only to the analyzed species but also to the chemical basis of the assays. In addition, regression analysis determined the correlation between the results obtained by the different methods. A strong correlation among different assays as well as with anthocyanin content was observed. Cluster analysis can be used in food science, to classify different food types into groups, based on similarity among the results.

\section{Acknowledgements}

The research was supported by the Ministry of Education and Science of the Republic of Serbia [172051]. Marija Dimitrijevic and Jelena Cvetkovic are grateful to the Ministry of Education and Science of the Republic of Serbia for providing scholarships for researchers.

\section{References}

[1] Saha M.N., Alam M.A., Aktar R., Jahangir R., In vitro free radical scavenging activity of Ixora coccinea L., Bangladesh J. Pharmacol. 3 (2008) 90-96.

[2] Shi H., Noguchi N., Niki E., Introducing natural antioxidants, in: Pokorny J., Yanishlieva N., Gordon M. (Eds.), Antioxidants in food, Practical applications, Woodhead Publ., Camb., U.K., 2001.

[3] Vaya J., Aviram M., Nutritional antioxidants: mechanism of action, analyses of activities and medical applications, Curr. Med. Chem.: Immunol. Endocr. \& Metab. Agents 1 (2009) 99-117.

[4] Kaur C., Kapoor H.C., Antioxidants in fruits and vegetables - the millennium's health, $\mathrm{J}$. Food Sci. Technol. 36 (2001) 703-725.

[5] Rice-Evans C.A., Miller N.J., Paganga G., Structure-antioxidant activity relationships of flavonoids and phenolic acid, Free Radic. Biol. Med. 20 (1996) 933-956.

[6] Gordon A., Friedrich M., Da Matta V.M., Herbster Moura C.F., Marx F., Changes in phenolic composition, ascorbic acid and antioxidant capacity in cashew apple (Anacardium occidentale $\mathrm{L}$.) during ripening, Fruits 67 (2012) 267-276.

[7] Meyers K.J., Watkins C.B., Pritts M.P., Liu R.H., Antioxidant and antiproliferative activities of strawberries, J. Agric. Food Chem. 51 (2003) 6887-6892.

[8] Benvenuti S., Pellati F., Melegari M., Bertelli D., Polyphenols, anthocyanins, ascorbic acid, and radical scavenging activity of Rubus, Ribes, and Aronia, J. Food Sci. 69 (2004) 164-169.

[9] Hegedus A., Balogh E., Engel R., Sipos B.Z., Papp J., Blazovics A., Stefanovits-Bányai E., Comparative nutrient element and antioxidant characterization of berry fruit species and cultivars grown in Hungary, HortScience 43 (2008) 1711-1715.

[10] Garzon G.A., Riedl K.M., Schwartz S.J., Determination of anthocyanins, total phenolic content, and antioxidant activity in Andes berry (Rubus glaucus Benth.), J. Food Sci. 74 (2009) 227-232. 
[11] Nour V., Trandafir I., Ionica M.E., Ascorbic acid, anthocyanins, organic acids and mineral content of some black and red currant cultivars, Fruits 66 (2011) 353-362.

[12] Katsube N., Iwashita K., Tsushida T., Yamaki K., Kobori M., Induction of apoptosis in cancer cells by bilberry (Vaccinium myrtillus) and the anthocyanins, J. Agric. Food Chem. 51 (2003) 68-75.

[13] Garzon G.A., Riedl K.M., Schwartz S.J., Determination of anthocyanins, total phenolic content, and antioxidant activity in Andes berry (Rubus glaucus Benth.), J. Food Sci. 74 (2009) C227-C232.

[14] Kammerer D.R., Schillmoller S., Maier O., Schieber A., Carle R., Colour stability of canned strawberries using black carrot and elderberry juice concentrates as natural colourants, Eur. Food Res. Technol. 224 (2007) 667-679.

[15] Beekwilder J., Jonker H., Meesters P., Hall R.D., van der Meer I.M., de Vos C.H.R., Antioxidants in raspberry: on-line analysis links antioxidant activity to a diversity of individual metabolites, J. Agric. Food Chem. 53 (2005) 3313-3320.

[16] Meyers K.J., Watkins C.B., Pritts M.P., Liu R.H., Antioxidant and antiproliferative activities of strawberries, J. Agric. Food Chem. 51 (2003) 6887-6892.

[17] Wattenberg L.W., Inhibition of carcinogenesis by minor dietary constituents, Cancer Res. 52 (1992) 2085-2091.

[18] Duthie G.G., Gardner P.Y., Kyle J.A.M., Plant polyphenols: Are they the new magic bullet? Proc. Nutr. Soc. 62 (2003) 599-603.

[19] Dai Q., Borenstein A.R., Wu Y., Jackson J.C. Larson E.B., Fruit and vegetable juices and Alzheimer's disease: The Kame Project, Am. J. Med. 119 (2006) 751-759.

[20] Määttä-Riihinen K.R., Kamal-Eldin A., Mattila P.H., González-Paramás A.M., Törrönen A.R., Distribution and content of phenolic compounds in eighteen scandinavian berry species, J. Agric. Food Chem. 52 (2004) 4477-4486.

[21] Giusti M.M., Wrolstad R.E., Anthocyanins: characterization and measurement with UVvisible spectroscopy, in: Wrolstald R.E. (Ed.), Current protocols in food analytical chemistry, John Wiley \& Sons, N.Y., U.S.A., 2001.

[22] Cherif J.K., M'Rabet I., El Habiri M., Abidi R., Albrecht-Gary A.M., Mesure de l'activité antiradicalaire du jus et des peaux d'oranges tunisiennes par le radical DPPH, Fruits 61 (2006) 99-107.

[23] Re R., Pellegrini N., Proreggente A., Pannala A., Yang M., Rice-Evans C., Antioxidant activity applying an improved ABTS radical cation decolorization assay, Free Radic. Biol. Med. 26 (1999) 1231-1237.

[24] Lim Y.S., Lee S.S.H., Tan B.C., Antioxidant capacity and antibacterial activity of different parts of mangosteen (Garcinia mangostana Linn.) extracts, Fruits 68 (2013) 483-489.

[25] Oyaizu M., Studies on products of the browning reaction. Antioxidative activities of browning reaction products prepared from glucosamine, Jpn. J. Nutr. 44 (1986)307-315.

[26] Chaieb N., González J.L., López-Mesas M., Bouslama M., Valiente M., Polyphenols content and antioxidant capacity of thirteen faba bean (Vicia faba L.) genotypes cultivated in Tunisia, Food Res. Int. 44 (2011) 970-977.

[27] Tomsone L., Kruma Z., Alsina I., The application of hierarchical cluster analysis for classifying horseradish genotypes (Armoracia rusticana L.) roots, Chem. Technol. 4 (2012) 52-56.

[28] Wang S.Y., Lin H.S., Antioxidant activity in fruit and leaves of blackberry, raspberry and strawberry varies with cultivar and developmental stage, J. Agric. Food Chem. 48 (2000) 140-146.

[29] Pantelidis G.E., Vasilakakis M., Manganaris G.A., Diamantidis G., Antioxidant capacity, phenol, anthocyanin and ascorbic acid contents in raspberries, blackberries, red currants, gooseberries and Cornelian cherries, Food Chem. 102 (2007) 777-783.

[30] Lee J., Durst R.W., Wrolstad R.E., Determination of total monomeric anthocyanin pigment content of fruit juices, beverages, natural colorants, and wines by the $\mathrm{pH}$ differential method: collaborative study, J. AOAC Int. 88 (2005) 1269-1278.

[31] Sarma A.D., Sharma R., Anthocyanin-DNA copigmentation complex: mutual protection against oxidative damage, Phytochem. 52 (1999) 1313-1318.

[32] Tsuda T., Horio F., Osawa T., The role of anthocyanins as an antioxidant under oxidative stress in rats, BioFactors 13 (2000) 133-139.

[33] Wang G.P., Cahill S.M., Liu X., Girvin M.E., Grubmeyer C., Motional dynamics of the catalytic loop in OMP synthase, Biochem. 38 (1999) 284-295.

[34] Tumbas V.T., Mandić A.I., Ćetković G.S., Đilas S.M., Čanadanović-Brunet J.M., HPLC analysis of phenolic acids in mountain germander (Teucrium montanum L.) extracts, APTEFF 35 (2004) 1-280.

[35] Fernández de Simón B., Pérez-llzarbe J., Hernández T., Gómez-Cordovés C., Estrella I., HPLC study of the efficiency of extraction of phenolic compounds, Chromatogr. 30 (1990) 35-37. 
[36] Soobrattee, M.A., Neergheen V.S., LuximonRamma A., Aruoma O.I., Bahorun T., Phenolics as potential antioxidant therapeutic agents: mechanism and actions, Mutat. Res. 579 (2005) 200-213.

[37] Stratil P., Klejdus B., Kubáň V., Determination of phenolic compounds and their antioxidant activity in fruits and cereals, Talanta 71 (2007) 1741-1751.

[38] Wootton-Bearda P.C., Morana A., Ryan L., Stability of the total antioxidant capacity and total polyphenol content of 23 commercially available vegetable juices before and after in vitro digestion measured by FRAP, DPPH, ABTS and Folin-Ciocalteu methods, Food Res. Int. 44 (2011) 217-224.

[39] Wu X., Beecher R., Holden J.M., Haytowitz D.B., Gebhardt S.E., Prior R.L., Lipophilic and hydrophilic antioxidant capacities of common foods in the United States, J. Agric. Food Chem. 52 (2004) 4026-4037.

[40] Prior R.L., Wu X., Schaich K., Standardized methods for the determination of antioxidant capacity and phenolics in foods and dietary supplements, J. Agric. Food Chem. 53 (2005) 4290-4302.

[41] Ou B., Huang D., Hampsch-Woodill M., Flanagan J.A.J., Deemer E.K., Analysis of antioxidant activities of common vegetables employing oxygen radical absorbance capacity (ORAC) and ferric reducing antioxidant power (FRAP) assays: a comparative study, J. Agric. Food Chem. 50 (2002) 31223128.

[42] Pellegrini N., Serafini M., Colombi B., Del Rio D., Salvatore S., Bianchi M., Brighenti F., Total antioxidant capacity of plant foods, beverages and oils consumed in Italy assessed by three different in vitro assays, $\mathrm{J}$. Nutr. 133 (2003) 2812-2819.

[43] Rice-Evans C.A., Miller N.J., Bolwell P.G., Bramley P.M., Pridham J.B., The relative antioxidant activities of plant-derived polyphenolic flavonoids, Free Radic. Res. 22 (1995) 375-383.

[44] Takahata Y., Kai Y., Tanaka M., NakayamaH., Yoshinaga M., Enlargement of the variances in amount and composition of anthocyanin pigments in sweet potato storage roots and their effect on the differences in DPPH radical-scavenging activity, Sci. Hortic. 2011 127 (4) 469-474.

[45] Cho M.J., Howard L.R., Prior R.L., Clark J.R., Flavonoid glycosides and antioxidant capacity of various blackberry, blueberry and red grape genotypes determined by high-performance liquid chromatography/ mass spectrometry, J. Sci. Food Agric. 84 (2004)1771-1782.

\section{Análisis quimiométrico de la actividad antioxidante y del contenido de} antocianinas de frutos blandos silvestres y cultivados en Serbia.

Resumen - Introducción. Los frutos como las frambuesas (Rubus idaeus), las cerezas (Prunus cerasus), las moras (Rubus fructicosus), las endrinas (Prunus spinosa) y Aronia melanocarpa son muy frecuentes en Serbia. Estos frutos representan una valiosa fuente de antioxidantes. Nuestro trabajo pretendió evaluar las actividades antioxidantes de los extractos de acetato de etilo de estos cinco frutos blandos y establecer una correlación posible entre el contenido de las antocianinas y la actividad antioxidante. Material y métodos. Para determinar la actividad antioxidante de los frutos seleccionados, se emplearon los métodos DPPH (2,2-difenil-1-picrilhidracil), ABTS (ácido 2,2-azinobis-3-etilbenzotiazolin-6-sulfónico), FRAP (poder antioxidante de reducción del hierro) y TRP (poder reductor total) en extractos de los cinco frutos seleccionados. Resultados. Los cuatro métodos empleados para nuestros ensayos revelaron las grandes propiedades antioxidantes de las muestras de moras. El contenido total de antocianinas se estimó mediante el uso del método de la diferencia de $\mathrm{pH}$. El contenido más elevado de antocianina se encontró en las muestras de moras [(1063,53 \pm $0.01) \mathrm{mg} \cdot \mathrm{kg}^{-1}$ materia fresca], y la más floja en las muestras de frambuesas $\left[(180,84 \pm 0.02) \mathrm{mg} \cdot \mathrm{kg}^{-1}\right.$ materia fresca]. La correlación entre el contenido de antocianinas y la actividad antioxidante se estableció por análisis de regresión. La correlación más fuerte se encontró entre el método TRP y las antocianinas totales $(r=0,97, p<0,05)$. El análisis de clasificación jerárquico dividió las especies fruteras seleccionadas en dos grupos estadísticamente significativos. Conclusión. Nuestros resultados confirmaron que los frutos analizados eran ricos en antocianinas. Se observó una fuerte correlación entre el uso de los diferentes métodos y el contenido de antocianinas. El análisis tipológico podría emplearse en la ciencia de los alimentos para clasificar diferentes tipos de producción en grupos, basándose en una similitud entre los resultados.

Serbia / Rubus idaeus / Prunus cerasus / Rubus fructicosus / Prunus spinosa / Aronia melanocarpa / frutas / antioxidantes / antocianinas / metodología 